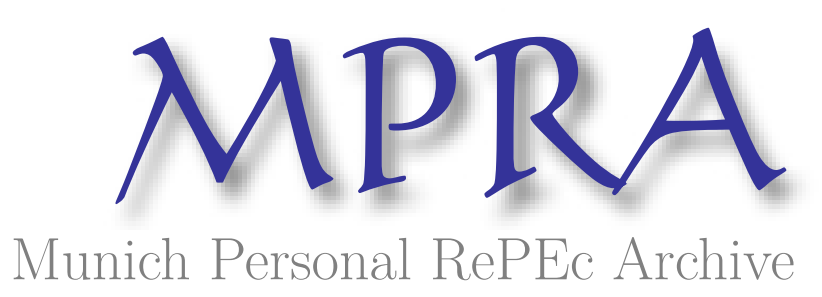

\title{
Does currency substitution affect exchange rate uncertainty? the case of Turkey
}

Levent, Korap

Istanbul University Institute of Social Sciences, Besim Ömer Paşa

Cd. Kaptan-ı Derya Sk. 34452 Beyazıt /ISTANBUL

2007

Online at https://mpra.ub.uni-muenchen.de/20319/

MPRA Paper No. 20319, posted 30 Jan 2010 08:25 UTC 


\title{
DOES CURRENCY SUBSTITUTION AFFECT EXCHANGE RATE UNCERTAINTY? THE CASE OF TURKEY
}

\section{Cem SAATÇİOĞLU}

Istanbul University, Faculty of Economics, Department of Economics, İstanbul / TURKEY

Cihan BULUT

Qafqaz University, Faculty of Economics, Department of International Economics, Baku / AZERBAIJAN

H. Levent KORAP

Economist, Marmara University, İstanbul / TURKEY

\begin{abstract}
In this paper, we investigate whether the currency substitution can affect the exchange rate uncertainty for the Turkish economy. Considering the whole time period 1987M01-2006M12 as well as thesub-periods 1987M01-1999M12 and 2001M03-2006M12 for sensitivity analysis, our estimation results employing contemporaneous exponential GARCH (EGARCH) methodology of Nelson (1991) indicate that currency substitution leads to the exchange rate uncertainty. Besides, conditional variance reacts more to past positive shocks than to negative innovations of equal size.
\end{abstract}

Keywords: Exchange rate, dollarization, currency substitution, inflation, exponential GARCH models, conditional variance, leverage effect, Turkish economy

\section{INTRODUCTION}

One of the salient characteristics of high inflation countries is that economic agents tend to increase to a great extent switch from holding of domestic currency to the foreign currencies as a means of exchange or as a store of value in line with the precautionary motive to demand 
for money. As Choudhry (1995) expresses, demand for exchange rate alternative to holding real money balances in domestic currency may provide evidence of currency substitution in high inflation countries, which reduces domestic monetary control as well as base for inflation tax. Thus, due to the lack of foreseeing future courses of domestic economy, increasing demand for exchange rate as a hard currency ensures that economic agents can hedge somewhat the real value of their wealth against high depreciation of real money stocks under a chronic or high inflationary framework, which in turn increases dollarization of the economy such as Turkey, subject to inflationary pressures over a two-decades period.

When considered with a highly instable real income growth process dominated in the Turkish economy by the late-1980s and whole 1990s, the Turkish economy witnessed that a substantial currency substitution phenomenon dominated the course of domestic financial system. Beginning by the liberalization of foreign currency holdings in 1983 and of foreign currency controls in 1989, Turkish currency depreciated in considerable amount that led the domestic residents to increase foreign currency holdings in their financial wealths rather than to demand for domestic currency or assets. This phenomenon accelerates especially for the post-1992/93 period in the sense that the ratio of foreign exchange deposits in the whole financial system represented by the sum of currency in circulation plus domestic currencybased demand and time deposits and also foreign exchange deposits is above $40 \%$ till the end of 2004, and in some sub-periods such as April-1994 and post-February 2001 economic crises, exceeds $50 \%$ with an increased volatility in financial crisis periods. And such a structural change in the economy may easily raise some questions about the stability of the whole financial system (Koğar, 1995). ${ }^{1}$

Many papers emphasize the importance of currency substitution on the Turkish economy. ${ }^{2}$ Selçuk (1994) finds that domestic residents have a preference for substituting foreign currencies for domestic currency because of real exchange rate depreciations, and that a policy aiming to increase the expected real return on domestic assets is required for reversing this process. Likewise, Selçuk (1997) reveals that the share of foreign balances in the production of money services in Turkey is quite high and that foreign exchange deposits are

\footnotetext{
${ }^{1}$ See Ertuğrul and Selçuk (2002) for an overview of the Turkish economy for the post-1980 period.

${ }^{2}$ Giovannini and Turtelboom (1992), Yilmaz (2005) and Civcir (2005) touch on the difference between the terms dollarization and currency substitution in the sense that in high inflation countries foreign currency is first used as a store of value or unit of account representing dollarization and only at the later used as a medium of exchange. That is, currency substitution is the last stage of the dollarization process.
} 
strong substitute for the Turkish Lira. Alçay et al. (1997) examine the extent of currency substitution and its effects on exchange rate instability and find evidence in favor of that exchange rate instability increases with the degree of currency substitution. Also Şıklar (1998), Selçuk (2002) and Soydan (2003) try to estimate the effect of currency substitution on seigniorage revenue for the Turkish economy. Bahmani-Oskooee and Domaç (2002) investigate the role of dollarization in the dynamics of inflation such as monetary base and administered prices. Civcir (2005) finds interest rate differential and the expected exchange rates as the dominant factors in determining dollarization. ${ }^{3}$ Thus many different aspects of currency substitution have been tried to be explored empirically on the Turkish economy.

In this paper, our aim is to shed some light upon the possible effect of currency substitution on exchange rate uncertainty such as Akçay et al. (1997), but by extending the time period till the end of 2006 as well as employing a sensitivity analysis considering two different time periods subject to structural changes in the Turkish economy. The next section highlights the methodological issues in estimation process. Section III tries to construct an empirical model upon the Turkish economy, while section IV is devoted to sensitivity analysis of the empirical findings to some sub-periods in line with structural changes in the Turkish economy. And the final section concludes.

\section{METHODOLOGY}

The traditional generalized ARCH (GARCH) methodology of Bollerslev (1986) and its more recent variants such as treshold GARCH (TARCH) proposed by Zakoïan (1994) and Glosten et al. (1993), exponential GARCH proposed by Nelson (1991), power ARCH (PARCH) generalized in Ding et al. (1993) and also component GARCH (CGARCH) models have been widely used in economics literature to measure the volatility pattern of financial time series or to proxy the uncertainty in economic modeling. In our paper, we apply to a similar methodology to Domaç and Mendoza (2004) employing EGARCH methodology on Turkish financial time series and aim at revealing the information content of volatility on exchange rate uncertainty conditional on a proxy for currency substitution in variance equation.

Following QMS (2004), the specification for conditional variance in EGARCH model is,

\footnotetext{
${ }^{3}$ An extensive theoretical and empirical literature on currency substitution can be found in Calvo and Végh (1992) and Giovannini and Turtelboom (1992).
} 


$$
\log \left(\sigma_{t}^{2}\right)=\omega+\sum_{j=1}^{q} \beta_{j} \log \left(\sigma_{t-j}^{2}\right)+\sum_{i=1}^{p} \alpha_{i}\left|\left(\varepsilon_{t-i}\right) /\left(\sigma_{t-i}\right)\right|+\sum_{k=1}^{r} \gamma_{k}\left[\left(\varepsilon_{t-k}\right) /\left(\sigma_{t-k}\right)\right]
$$

for which $\sigma_{t}^{2}$ gives the forecast variance based on past information, and is called the conditional variance. This implies that the leverage effect allowing the variance to respond differently following equal magnitude negative or positive shocks is exponential, rather than quadratic, and that forecasts of the conditional variance are guaranteed to be nonnegative. The impact would be asymmetric if $\gamma_{i} \neq 0$. There are a couple of differences between the EViews specification of the EGARCH model used in this paper and the original Nelson model. First, Nelson assumes that error term from mean equation, $\varepsilon_{t}$, follows a Generalized Error Distribution (GED), while EViews gives a choice of normal, Student's $t$-distribution, or GED. Second, Nelson's specification for the log conditional variance is a restricted version of:

$$
\log \left(\sigma_{t}^{2}\right)=\omega+\sum_{j=1}^{q} \beta_{j} \log \left(\sigma_{t-j}^{2}\right)+\sum_{i=1}^{p} \alpha_{i} \mid\left[\left(\varepsilon_{t-i}\right) /\left(\sigma_{t-i}\right)-E\left[\left(\varepsilon_{t-i}\right) /\left(\sigma_{t-i}\right)\right] \mid+\sum_{k=1}^{r} \gamma_{k}\left[\left(\varepsilon_{t-k}\right) /\left(\sigma_{t-k}\right)\right](2)\right.
$$

which differs slightly from the specification above. Estimating this model will yield identical estimates to those reported by EViews except for the intercept term $\omega$, which will differ in a manner that depends upon the distributional assumption and the order $\mathrm{p}$. Also to deal with potential model misspecification, we have calculated robust $t$-ratios using the quasi maximum likelihood method suggested by Bollerslev and Wooldridge (1992) so that parameter estimates will be unchanged but the the estimated covariance matrix will be altered.

\section{ESTIMATION RESULTS}

Following these model specification issues, we use the exchange rate depreciation of the log difference form (E), i.e., TL/US\$ in first differences, in mean equation of the EGARCH specification for empirical purposes, and the whole time period consists of monthly observations beginning from 1987M01 till 2006M12 considering 239 observations, while 1987M01-1999M12 and 2001M03-2006M12 sub-periods will also be taken into account below for sensitivity analysis. Since the GARCH methodology requires stationary variables to employ regression analysis, we performed some preliminary unit root tests, and the results indicated that the TL/US\$ exchange rate is I(1), whereas the first differenced form leads us to 
that exchange rate return ensures the stationarity required for regression analysis. ${ }^{4}$ Descriptive statistics not reported here reveal that exchange rate series considered have a symmetric distribution around its mean through skewness statistics. Besides, there exists a normal kurtosis verifying the flatness of the distribution of the series under normal distribution. ${ }^{5}$

To find the possible effect of the currency substitution on exchange rate uncertainty, we include a proxy for currency substitution in the variance equation of the EGARCH model specification. For this purpose, we use the ratio of foreign exchange based accounts to the sum of currency in circulation plus domestic demand and time deposits (DOL), i.e., M2 monetary aggregate, in the Turkish financial system. We choose the autoregressive order of the exchange rate series considered by applying to lag information criterions of the unrestricted vector autoregression models conditional on the series itself as endogenous variable. All five information criterions, i.e. Sequential Modified Likelihood Ratio (LR), Final Prediction Error (FPE), Akaike Information Criterion (AIC), Schwarz Information Criterion and Hannan-Quinn Information Criterion, suggest 1 lag order for the whole period 1987M012006M12 and for the sub-period 1987M01-1999M12 periods, while LR and SC statistics suggest 1, FPE and AIC statistics suggest 3 and HQ statistics suggest 2 lag orders for the subperiod 2001M03-2006M12.

Following these model specification issues, we try to estimate the EGARCH-M model of the exchange rate letting also conditional variance affect the mean equation. For this purpose, we give the EViews 5.1 output of the estimated mean and variance equations in Table 1 below.

EGARCH estimation results reveal that no significant effect of conditional variance on the mean equation can be detected. Autoregressive coefficient indicates a positive effect on the mean level of exchange rate return. We estimate in Table 1 that EGARCH parameter, which measures the degree of how persistent is the volatility shocks, is statistically significant and seems to be persistent so that the forecasts of the conditional variance converge to the steady state somewhat slowly. The leverage effect term, $\gamma$, denoted as C(6)*RESID(1)/@SQRT(GARCH(-1)) in the output, is positive and statistically different from zero indicating that the news impact is asymmetric, thus, the existence of the leverage effect during

\footnotetext{
${ }^{4}$ The ADF $t$-statistic is $-2.21(-9.28)$ assuming only constant and $0.78(-9.69)$ assuming both constant and trend terms in the test equation, of which the differenced values are in parentheses. The relevant $5 \%$ test critical values are -2.87 and -3.43 , respectively, under the null of a unit root.

${ }^{5}$ These estimation results not reported here to save space are available from the authors upon request.
} 
TABLE 1: EGARCH ESTIMATION RESULTS (1987M01-2006M12)

\begin{tabular}{|c|c|c|c|c|}
\hline \multicolumn{5}{|c|}{ Dependent Variable: E } \\
\hline \multicolumn{5}{|c|}{ Method: ML-ARCH (Marquardt) - Normal Distribution } \\
\hline \multicolumn{5}{|c|}{ Sample (adjusted): 1987M03 2006M12 } \\
\hline \multicolumn{5}{|c|}{ Included observations: 238 after adjustments } \\
\hline \multicolumn{5}{|c|}{ Bollerslev-Wooldridge robust standard errors \& covariance } \\
\hline \multicolumn{5}{|c|}{ Variance backcast: ON } \\
\hline \multicolumn{5}{|c|}{$\mathrm{LOG}(\mathrm{GARCH})=\mathrm{C}(4)+\mathrm{C}(5) * \mathrm{ABS}(\mathrm{RESID}(-1) /(\mathrm{SQRT}(\mathrm{GARCH}(-1)))+$} \\
\hline \multicolumn{5}{|c|}{$\mathrm{C}(6) * \operatorname{RESID}(-1) / @ \operatorname{SQRT}(\mathrm{GARCH}(-1))+\mathrm{C}(7) * \mathrm{LOG}(\mathrm{GARCH}(-1))+\mathrm{C}(8) * \mathrm{DOL}$} \\
\hline & Coefficient & Std.Error & z-Statistic & Prob. \\
\hline GARCH & -1.875526 & 1.508739 & -1.243109 & 0.2138 \\
\hline $\mathrm{C}$ & 0.012551 & 0.002370 & 5.296331 & 0.0000 \\
\hline $\mathrm{E}(-1)$ & 0.629374 & 0.060026 & 10.48503 & 0.0000 \\
\hline \multicolumn{5}{|c|}{ Variance Equation } \\
\hline $\mathrm{C}(4)$ & -3.974391 & 0.912934 & -4.353426 & 0.0000 \\
\hline$C(5)$ & 0.766682 & 0.139570 & 5.493159 & 0.0000 \\
\hline$C(6)$ & 0.306509 & 0.123854 & 2.474754 & 0.0133 \\
\hline$C(7)$ & 0.613066 & 0.100270 & 6.114138 & 0.0000 \\
\hline $\mathrm{C}(8)$ & 0.858249 & 0.367445 & 2.335717 & 0.0195 \\
\hline AIC & -4.386020 & & & \\
\hline $\mathrm{SC}$ & -4.269305 & & & \\
\hline \multicolumn{5}{|c|}{$\mathrm{Q}(1)=1.29(0.26), \mathrm{Q}(12)=13.46(0.34), \mathrm{Q}^{2}(1)=0.09(0.76), \mathrm{Q}^{2}(12)=0.97(0.99)$} \\
\hline \multicolumn{5}{|l|}{ ARCH LM(12) } \\
\hline F-statistic & 0.065764 & Prob. F(12,213) & 0.99 & \\
\hline Obs*R-squared & 0.834241 & Prob. Chi-Squal & $\operatorname{are}(12) 0.99$ & \\
\hline
\end{tabular}

the sample period. The positive and significant coefficient of the proxy used for currency substitution supports the findings of Akçay et al. (1997) in the sense that the higher the currency substitution the higher is the uncertainty attributed to the exchange rate return. Dealing with diagnostics where probs. are given in parentheses, correlogram-Q statistics for the presence of autocorrelation in the standardized residuals and in the squares of standardized residuals cannot reject the null at conventional levels in the sense that no remaining serial correlation in the mean equation is detected. 
One way of further examining the distribution of the standardized residuals is to plot the quantiles. If the residuals are normally distributed, the points in the Quantile-Quantile (QQ) plots should lie alongside a straight line. We see below in Figure 1 that it is primarily large positive shocks that are driving the departure from normality:

\section{FIGURE 1: QUANTILE-QUANTILE GRAPH}

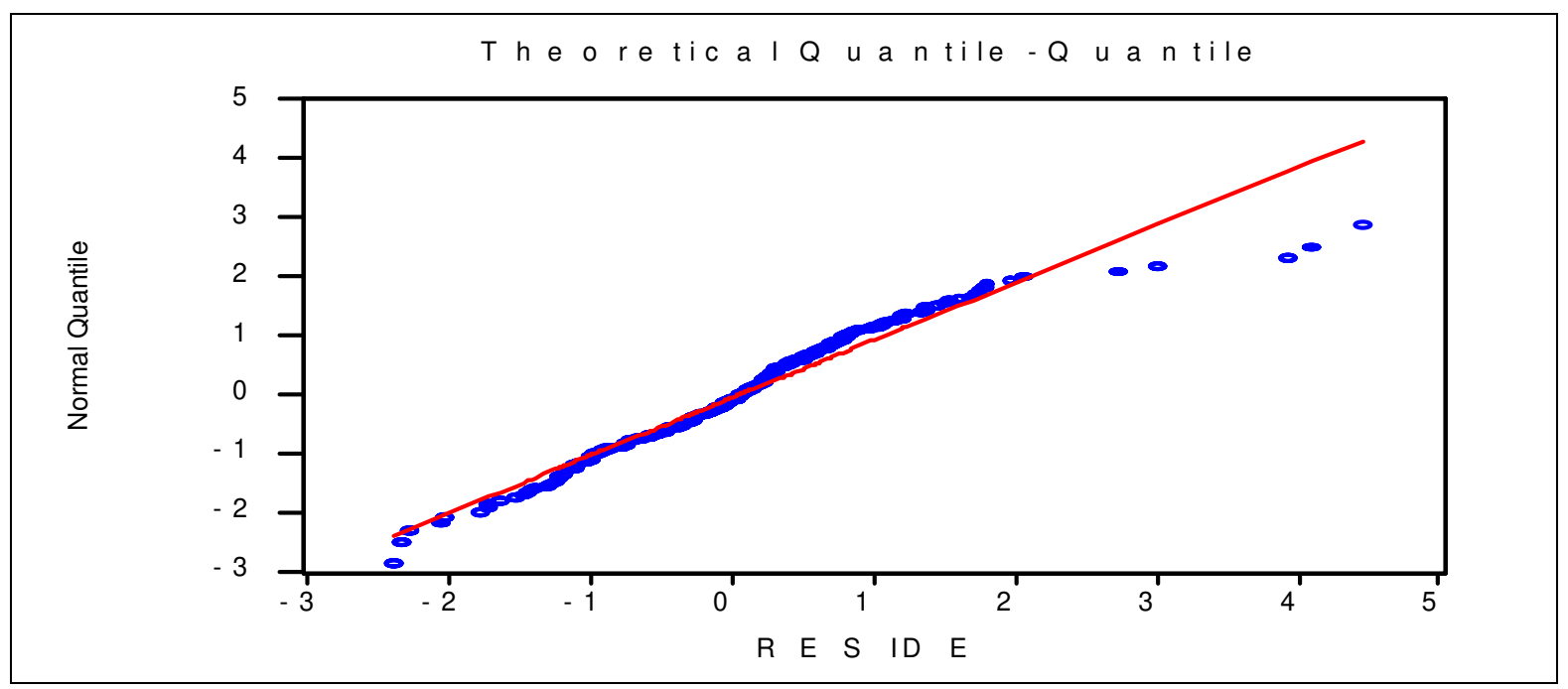

Having established the EGARCH model for the whole period considered, we now plot the News Impact Curve (NIC) using EViews 5.1. Our goal is here to plot the volatility $\sigma^{2}$, against the impact $\mathrm{z}=\varepsilon / \sigma$, where:

$$
\begin{gathered}
\wedge \\
\log \sigma_{t}^{2}=\omega+\beta \log \sigma_{t-1}^{2}+\alpha\left|z_{\mathrm{t}-1}\right|+\gamma \mathrm{z}_{\mathrm{t}-1}
\end{gathered}
$$

We will fix last period's volatility $\sigma_{t-1}^{2}$ to the median of the estimated conditional variance series and estimate the one-period impact, conditional on last period's volatility. Below is shown the NIC of inflation in Figure 2.

An asymmetric leverage effect can easily be noticed in Figure 2 supporting the estimation results in Table 1 above. We can here conclude that the conditional variance reacts more to past positive shocks than to negative innovations of equal size. 
FIGURE 2: NEWS IMPACT CURVE

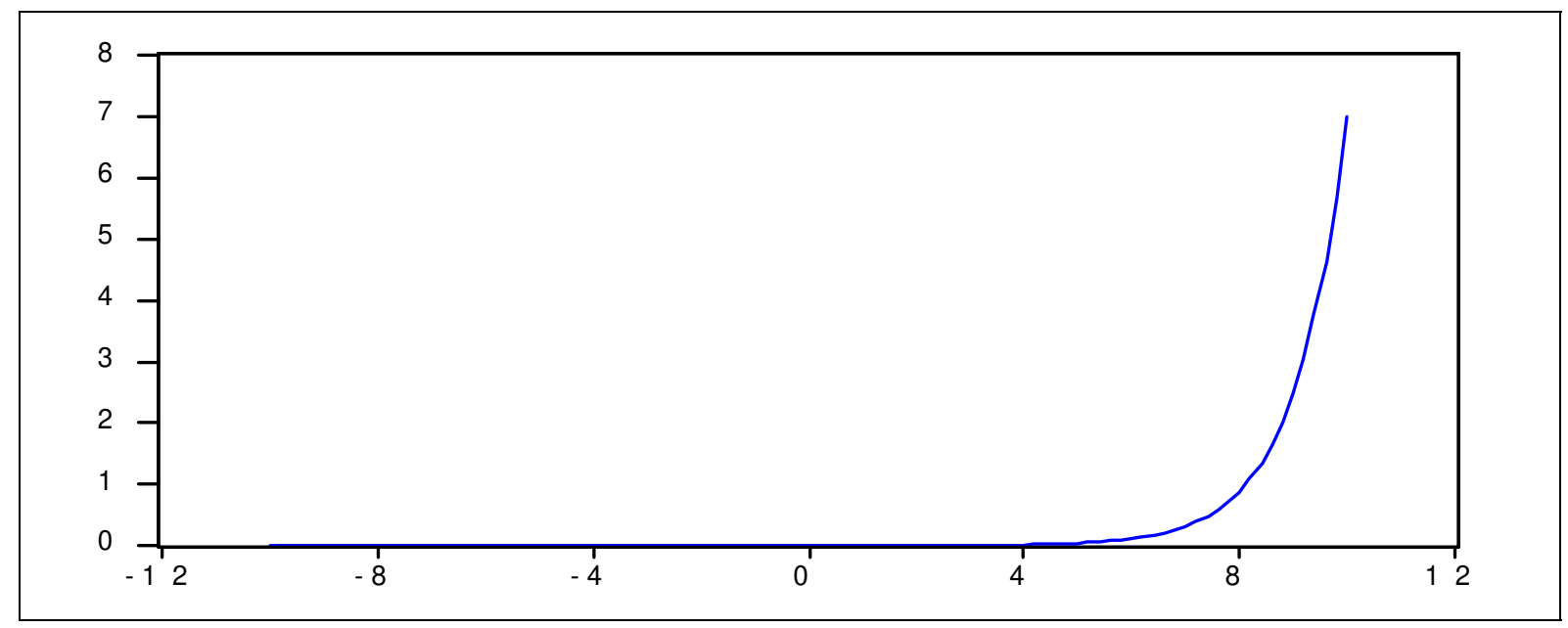

\section{SENSITIVITY ANALYSIS}

We now conduct some robustness tests to the empirical analysis above and try to find whether estimation results in Table 1 can be supported using the data in sub-periods. For this purpose, the first sub-period consists of the data from 1987M01-1999M12, and the second sub-period from 2001M03-2006M12. We have excluded the period of 2000 anti-inflationary stabilization program and the subsequent two crises periods from the analysis for they constitute a structural break point in the Turkish economy, which cannot be fully reconciled with any of the two periods expressed above. Regression results can be seen in Table 2 and Table 3 below.

Our findings from both sub-periods verify the estimates of the whole period. For 1987M011999M12, one-period lagged autoregressive coefficient in the mean equation is positive and statistically significant, while it loses it significance for the latter sub-period. EGARCH and leverage parameters follow the characteristics from the main period revealing again that past positive shocks affect the conditional variance predominantly. Supporting the above findings, currency substitution leads to more uncertainty for the exchange rate return. Both sub-periods have good diagnostics, as well. 
TABLE 2: EGARCH ESTIMATION RESULTS (1987M01-1999M12)

\begin{tabular}{|c|c|c|c|c|}
\hline \multicolumn{5}{|c|}{ Dependent Variable: E } \\
\hline \multicolumn{5}{|c|}{ Method: ML-ARCH (Marquardt) - Normal Distribution } \\
\hline \multicolumn{5}{|c|}{ Sample (adjusted): 1987M03 1999M12 } \\
\hline \multicolumn{5}{|c|}{ Included observations: 154 after adjustments } \\
\hline \multicolumn{5}{|c|}{ Bollerslev-Wooldridge robust standard errors \& covariance } \\
\hline \multicolumn{5}{|c|}{$\mathrm{LOG}(\mathrm{GARCH})=\mathrm{C}(4)+\mathrm{C}(5) * \mathrm{ABS}(\operatorname{RESID}(-1) / @ \operatorname{SQRT}(\mathrm{GARCH}(-1)))+$} \\
\hline \multicolumn{5}{|c|}{$\mathrm{C}(6) * \operatorname{RESID}(-1) / @ \mathrm{SQRT}(\mathrm{GARCH}(-1))+\mathrm{C}(7) * \mathrm{LOG}(\mathrm{GARCH}(-1))+\mathrm{C}(8) * \mathrm{DOL}$} \\
\hline & Coefficient & Std.Error & z-Statistic & Prob. \\
\hline GARCH & -1.566835 & 5.347698 & -0.292992 & 0.7695 \\
\hline $\mathrm{C}$ & 0.011622 & 0.002341 & 4.965474 & 0.0000 \\
\hline $\mathrm{E}(-1)$ & 0.721554 & 0.080542 & 8.958682 & 0.0000 \\
\hline \multicolumn{5}{|c|}{ Variance Equation } \\
\hline $\mathrm{C}(4)$ & -3.522193 & 1.247329 & -2.823788 & 0.0047 \\
\hline$C(5)$ & 0.364788 & 0.162283 & 2.247860 & 0.0246 \\
\hline$C(6)$ & 0.559030 & 0.113914 & 4.907478 & 0.0000 \\
\hline $\mathrm{C}(7)$ & 0.624206 & 0.140311 & 4.448720 & 0.0000 \\
\hline $\mathrm{C}(8)$ & 0.518190 & 0.272113 & 1.904318 & 0.0569 \\
\hline AIC & -4.842810 & & & \\
\hline $\mathrm{SC}$ & -4.685046 & & & \\
\hline \multicolumn{5}{|c|}{$\mathrm{Q}(1)=0.03(0.87), \mathrm{Q}(12)=6.39(0.90), \mathrm{Q}^{2}(1)=0.44(0.51), \mathrm{Q}^{2}(12)=2.31(0.99)$} \\
\hline \multicolumn{5}{|l|}{ ARCH LM(12) } \\
\hline F-statistic & 0.164059 & Prob. F(12 & 0.9 & \\
\hline Obs*R-squared & 2.134532 & Prob. Chi- & dare(12) 0.9 & \\
\hline
\end{tabular}


TABLE 3: EGARCH ESTIMATION RESULTS (2001M03-2006M12)

\begin{tabular}{|c|c|c|c|c|}
\hline \multicolumn{5}{|c|}{ Dependent Variable: E } \\
\hline \multicolumn{5}{|c|}{ Method: ML-ARCH (Marquardt) - Normal Distribution } \\
\hline \multicolumn{5}{|c|}{ Sample (adjusted): 2001M03 2006M12 } \\
\hline \multicolumn{5}{|c|}{ Included observations: 70 after adjustments } \\
\hline \multicolumn{5}{|c|}{ Bollerslev-Wooldridge robust standard errors \& covariance } \\
\hline \multicolumn{5}{|c|}{$\mathrm{LOG}(\mathrm{GARCH})=\mathrm{C}(4)+\mathrm{C}(5) * \mathrm{ABS}(\operatorname{RESID}(-1) / @ \operatorname{SQRT}(\mathrm{GARCH}(-1)))+$} \\
\hline \multicolumn{5}{|c|}{$\mathrm{C}(6) * \mathrm{RESID}(-1) / @ \mathrm{SQRT}(\mathrm{GARCH}(-1))+\mathrm{C}(7) * \mathrm{LOG}(\mathrm{GARCH}(-1))+\mathrm{C}(8) * \mathrm{DOL}$} \\
\hline & Coefficient & Std.Error & z-Statistic & Prob. \\
\hline GARCH & 17.70521 & 4.607933 & 3.842333 & 0.0001 \\
\hline $\mathrm{C}$ & -0.021604 & 0.005741 & -3.763330 & 0.0002 \\
\hline $\mathrm{E}(-1)$ & 0.024821 & 0.171049 & 0.145108 & 0.8846 \\
\hline \multicolumn{5}{|c|}{ Variance Equation } \\
\hline$C(4)$ & -3.611782 & 0.774249 & -4.664887 & 0.0000 \\
\hline$C(5)$ & 0.304720 & 0.131849 & 2.311120 & 0.0208 \\
\hline$C(6)$ & 0.544371 & 0.100579 & 5.412350 & 0.0000 \\
\hline$C(7)$ & 0.592919 & 0.100241 & 5.914906 & 0.0000 \\
\hline$C(8)$ & 0.742125 & 0.362967 & 2.044608 & 0.0409 \\
\hline AIC & -3.532852 & & & \\
\hline $\mathrm{SC}$ & -3.275881 & & & \\
\hline \multicolumn{5}{|c|}{$\mathrm{Q}(1)=1.21(0.27), \mathrm{Q}(12)=14.66(0.26), \mathrm{Q}^{2}(1)=0.15(0.70), \mathrm{Q}^{2}(12)=13.81(0.31)$} \\
\hline \multicolumn{5}{|l|}{ ARCH LM(12) } \\
\hline F-statistic & 0.958950 & Prob. $F(12,45)$ & 0.5 & \\
\hline Obs*R-squared & 11.81136 & Prob. Chi-Squa & $\operatorname{are}(12) 0.4$ & \\
\hline
\end{tabular}

\section{CONCLUSION}

In this paper, we try to investigate whether the currency substitution can affect the exchange rate uncertainty for the Turkish economy. Considering the whole time period 1987M12006M12 as well as the sub-periods 1987M01-1999M12 and 2001M03-2006M12 with quarterly observations, we apply to the contemporaneous exponential GARCH (EGARCH) methodology to bring out the volatility component of the TL/US\$ exchange rate, allowing the variance to respond differently following equal magnitude negative or positive shocks. Our findings indicate that for all the periods considered, the higher the currency substitution the 
higher is the uncertainty attributed to the exchange rate return. Besides, conditional variance reacts more to past positive shocks than to negative innovations of equal size.

Complementary papers as future researches employing more recent developments in contemporaneous estimation techniques will also help reserchers confirm whether the estimation results in this paper are in fact of the stylized facts for the Turkish economy.

\section{REFERENCES}

Akçay, O.C., Alper, C. E. and Karasulu, M. (1997), Currency substitution and exchange rate instability: The Turkish case, European Economic Review, 41, 827-835.

Bahmani-Oskooee, M. and Domaç, İ. (2002), On the link between dollarization and inflation: evidence from Turkey, CBRT Research Paper.

Bollerslev, T. (1986), Generalized autoregressive conditional heteroskedasticity, Journal of Econometrics, 31, 307-327.

Bollerslev, T. and Wooldridge, J. M. (1992), Quasi-maximum likelihood estimation and inference in dynamic models with time varying covariances, Econometric Reviews, 11, 143172.

Calvo, G. A. and Végh, C. A. (1992), Currency substitution in developing countries an introduction, Revista de Analysis Economico, 7/1, 3-28.

Choudhry, T. (1995), High inflation rates and the long-run money demand function: evidence from cointegration tests, Journal of Macroeconomics, 17/1, Winter, 77-91.

Civcir, İ. (2005), Dollarization and long-run determinants in Turkey, Research in Middle East Economics, 6, 201-232.

Ding, Z., Granger, C. W. J. and Engle, R. F. (1993), A long memory property of stock market returns and a new model, Journal of Empirical Finance, 1, 83-106. 
Domaç, İ. and Mendoza, A. (2004), Is there room for foreign exchange interventions under an inflation targeting framework?, World Bank Policy Research Working Paper, No. 3288, April.

Ertuğrul, A. and Selçuk, F. (2002), Turkish economy: 1980-2001, in A. Kibritçioğlu, L. Rittenberg and F. Selçuk (eds.), Inflation and Disinflation in Turkey, Ashgate Publishing Limited, 13-40.

Giovannini, A. and Turtelboom, B. (1992), Currency substitution, NBER Working Paper, December, 4232.

Glosten, L. R., Jaganathan, R. and Runkle, D. (1993), On the Relation between the Expected Value and the Volatility of the Normal Excess Return on Stocks, Journal of Finance, 48, 1779-1801.

Koğar, Ç. İ. (1995), Financial innovation and monetary control, CBRT Research Department Discussion Paper, No. 9515, May.

Nelson, D. B. (1991), Conditional heteroskedasticity in asset returns: a new approach, Econometrica, 59/2, March, 347-370.

QMS (2004), EViews 5 User's Guide, April.

Selçuk, F. (1994), Currency substitution in Turkey, Applied Economics, 26, 509-518.

Selçuk, F. (1997), GMM estimation of currency substitution in a high-inflation economy: evidence from Turkey, Applied Economics Letters, 4, 225-227.

Selçuk, F. (2002), Seigniorage, currency substitution and inflation in Turkey, in A. Kibritçioğlu, L. Rittenberg and F. Selçuk (eds.), Inflation and Disinflation in Turkey, Ashgate Publishing Limited, 155-166.

Soydan, A. (2003), Financial liberalization, currency substitution and seigniorage evidence from Turkey, Paper Presented to the Conference on Policy Modeling, July 3-5, Istanbul. 
Ş1klar, İ. (1998), Currency substitution and seigniorage revenue in a developing country: The Turkish case, Yapı Kredi Economic Review, 9/1, 3-14.

Yılmaz, G. (2005), Financial dollarization, (de)dollarization and the Turkish experience, Turkish Economic Association Discussion Paper, 2005/6.

Zakoïan, J. M. (1994), Threshold heteroskedastic models, Journal of Economic Dynamics and Control, 18, 931-944. 